\title{
IN-VISIONCONTINUITY ANNOUNCERS
}

\section{PERFORMING AN IDENTITY FOR EARLY TELEVISION IN EUROPE}

Sonja de Leeuw

Utrecht University

Muntstraat 2A

3512 EV Utrecht

The Netherlands

J.S.deLeeuw@uu.nl

Dana Mustata

University of Groningen

Media and Journalism Studies

Oude Kijk in 't Jatstraat 26

9712 EK Groningen

The Netherlands

D.Mustata@ruq.nl

\begin{abstract}
Female in-vision continuity announcers have played central - yet understudied and 'hidden'- roles in early television history. Through their performances on and off the screen, they mediated the identity of the televisual medium in the 1950s and 1960s, popularizing it as a medium of sound and vision, a domestic and gendered medium as well as a national and transnational institution. Focusing primarily on Dutch and Romanian female in-vision continuity announcers in the 1950s and 60s and making comparisons with other countries in Europe, this article illustrates how these early professionals of television performed as part of a European-wide phenomenon, defining the identity of the new televisual medium.
\end{abstract}

Keywords: In-Vision Continuity Announcers, European Television History, Netherlands, Romania.

While few scholarly works have been dedicated to in-vision continuity announcers, ${ }^{1}$ the richness of biographies, newspaper articles and interviews as well as online archival material bears testimony to the significant presence of these television personalities in the memory of television viewers. Browsing through the EUscreen online audiovisual collection, one can find various - yet strikingly similar - pictures and clips of female in-vision continuity announcers from across Europe. These similarities provoke a key question: is there something European about this particular television figure? Is there a particular role that in-vision announcers have played in the history of television across Europe?

1 See Hilde Van Den Bulck and Gunn Sara Enli, 'Bye Bye "Hello Ladies?" In-Vision Announcers as Technique in a European Postlinear Television Landscape: The Case of Flanders and Norway' in Television \& New Media, 17 October 2012, www.sagepublications.com, DOI: 10.1177/1527476412462143; James Bennett and Su Holmes discuss in passing BBC's in-vision announcers in relation to glamour and fame in: 'The 'place' of television in celebrity studies' in Celebrity Studies, 1:1, 2010, 65-80, DOI: 10.1080/19392390903519073; James Bennett discusses these issues in more detail, focusing on BBC's announcers as 'glamorous television personalities' in his book Television Personalities: Stardom and the Small Screen, Routledge, 2011. 
Van den Bulck and Enli discuss four key roles of in-vision announcers in the monopoly era of public broadcasting (1950s-1970s), arguing that: they've turned the television schedules into televisual flows, ensuring the continuity between different programmes; they've personalized television by addressing viewers directly and guiding them through their televisual experience; they've articulated the liveness of television by marking the 'here and now' of the viewing experience and last, but not least, they've become the image, brand or 'institutional emblem' of a national broadcaster.

In a similar vein, this article argues that female in-vision announcers across Europe mediated the identity of television as a new medium between the 1950s and 1970s. In this process of mediating televisual identity, they fulfilled European-wide roles that consisted of domesticating, popularizing and trans-nationalizing television. Female announcers put a face on a medium previously treated as radio with pictures, created an intimate link with television audiences and promoted national broadcast institutions within and across domestic borders. Much more than just a 'glamorous' 3 presence on the screen, female announcers played key roles in the history of early television in Europe.

What follows draws upon archival resources from nineteen broadcast archives in Europe and in-depth research into two specific countries: the Netherlands and Romania. Each of these countries represents different sides of the Iron Curtain as well as different public service broadcasting models. The Netherlands featured a so-called pillarized broadcasting model. The social concept of pillarization ran through Dutch culture and society from the 1920s on and translated into a segregated organization of Dutch culture and society, mainly according to Catholic, Christian Protestant, Liberal Protestant, Social Democratic, and Liberal foundations or 'pillars.' Dutch broadcasting at the time was organized according to this concept of pillarization and aimed at plural representation of the different religious and social groups in Dutch society. Romanian television, on the other hand, was part of a state-controlled broadcast institution that operated under a communist regime. Established in 1956, it functioned together with radio, as Radioteleviziunea Romana (Romanian Radiotelevision). It was initially placed under the supervision of the Radio and Television Committee of the Council of Ministers, an intermediary organ between the broadcasting institution and the Communist Party. By 1977, the institution came under the direct control of the Central Committee of the Communist Party. While Romanian television enjoyed a period of liberalization until the early 1970s, by the 1980s the institution became much more strictly policed by the ruling regime.

The article takes a comparative approach, focusing on these two countries, yet situating them within a broader European context by means of wider comparisons and references to other countries across the continent. The European comparative dimension of the article results from research done on the 'History of European Television' collection of EUscreen, to which nineteen broadcast archives in Europe have contributed. One of the strategies for the content selection behind this collection was to have the content providers upload material on what they considered to be 'popular figures' in their broadcast histories. The female continuity-announcer was by far the most popular selection, and the striking similarities behind the photographs and clips uploaded by most of the broadcast archives, bear testimony to the continuity-announcer being a salient part of an emergent and shared European television culture.

The in-depth research into Dutch and Romanian in-vision announcers drew on archival documentation at the Netherlands Institute for Sound and Vision (NISV) and Romanian Television's Archives, complemented by interviews with Dutch in-vision announcers conducted by NISV employees, interviews with Romanian in-vision announcers broadcast by Romanian television, biographies of both Romanian and Dutch in-vision announcers as well as related newspaper articles. The article is focused on the early period of television, starting from 1951 in the Netherlands and 1956 in Romania ${ }^{4}$ until 1965 in the Netherlands and 1971 in Romania, the year when most of the 'golden' announcers of Romanian television were hired. In both countries, this was the period when television searched for and eventually consolidated its own, particular identity.

\footnotetext{
2 Hilde Van Den and Gunn Sara Enli, 2012.

3 James Bennett, 2011.

${ }^{4}$ Dutch television was introduced in 1951, while Romanian television had its first broadcast on December 31st 1956.
} 


\section{The First Women of Television: The Screen Test}

In-vision announcers were some of the first women to work in and to appear on television. They were selected on the basis of their looks and voice, their appeal and performance in front of the camera, and their abilities to respond spontaneously together with their knowledge of foreign languages.

In the Netherlands, all announcers had to pass a first, and then a second screen test. At her first screen test, the Dutch announcer Mies Bouwman remembered she had to wear a black sweater and had to answer questions about what to do once the sound was off. She had to answer questions in English, read a page from a French book and then a newspaper clip in German. After her first test, she was asked for a second screen test and was instructed to wear either a flowered or a striped dress. She also received an assignment to prepare at home: read or summarize two acts of a theatre play ${ }^{5}$ At the second screen test Bouwman didn't perform well, but neither did the other two candidates who were also invited. They got another assignment to announce a musical piece in three minutes with very little preparation time. She finished her part by saying 'good evening, ladies and gentlemen and for later, sleep well'. Thereupon she was offered a contract.

At the test screens, in-vision announcers were expected to speak foreign languages and be able to articulate appropriately. They had no instructions on how they had to be dressed for the cameras. ${ }^{6}$ Bouwman recalls: 'if someone said that striped clothes went well with the screen, we all appeared in striped dresses. If someone else said we should stand diagonally in front of the camera, we all did so.'7

Later on, she (ironically) wrote down what her advice would be for future Dutch candidates applying for the job of invision announcer:

Be sure your Dutch is faultless, be sure you don't overdress and don't use too much make-up. Don't give any suggestions for programme improvement, don't criticise the past broadcasts, don't advocate a national broadcasting system [n.a. as opposed to the pillarized model of Dutch broadcasting] and don't order expensive consumables. Instead, behave like a girl who never or almost never saw television. Be sure to remember off the top of your head a very few top broadcasts of the broadcasting company you are dealing with, be sure not to mention you are a member of one of the other broadcasting companies [...] be sure to ask about wives and children. Don't speak about money. Then go home and wait. Once you are invited for a screen test, the great adventure starts and you will be awaited at the studio in Bussum wearing 'a light dress, preferably not black or white' as the invitation letter usually mentions. ${ }^{8}$

Bouwman satirized the pillarized broadcasting model in a way, suggesting female announcers would see through the behaviour of its male representatives. More implicitly, she pointed to the early stage of the profession and how Dutch announcers were expected to embody a certain (classic) style and class (middle class bourgeois), whilst not pretending they would be more then 'just' announcers, pushing them back into their gendered roles of remaining silent behind the scenes.

Video 1: Dutch announcer Karin Kraaykamp singing at the 5th anniversary of Dutch television about the etiquette of being an in-vision announcer, stressing one had to make 'no mistakes, speak your languages', be reliable and control your nerves, NTS 1956.

In Romania, the screen test for in-vision announcers consisted of the candidates sitting at a desk and reading different types of texts, from programme announcements to news items. They had to do real-time translations of foreign texts

\footnotetext{
5 Mies Bouwman, Goedenavond dames en heren! Close-ups en long shots uit de televisiewereld, De Boer jr., 1956, p. 59

6 Mies Bouwman, De Boer jr., 1956, p. 61-62.

7 Ibid.

8 Mies Bouwman, De Boer jr., 1956, p. 55-57.
} 
as well as read texts in French, Italian and English. During the screen test, the announcers were filmed in medium close-up alternating at times with close-ups of their facial features. As part of their screen test, there was also a catwalk where they had to walk up and down a stage in long evening gowns. During this catwalk performance, they were asked to stand under different lighting. ${ }^{9}$ Their expressivity and performance talents were carefully assessed during these screen tests.

It is worth emphasising at this point the fact that in both countries, in-vision announcers were required to speak different foreign languages, which testifies to the vision of television as a medium that would cross borders, with these female announcers being envisioned as the key trans-national links of television.

The selection of continuity announcers conformed to a particular ideology of middle-class femininity that these women were perceived to embody. This ideology articulated the idea of women choosing to embrace certain modes of femininity while making decisions between feminism and domesticity, between work-place and family life, between paid work and domestic labour..$^{10}$ This also articulated class and gender as a 'new age of "choiceoisie"'..$^{11}$ In socialist Romania, this coincided with the Communist Party's vision of the socialist woman embracing both a family and an active work life. Continuity announcers were selected to represent the ideals of domestic femininity, embodying the values of family life and traditional domesticity, as well as their independent careers on television. To become an announcer, candidates had to pass a screen test, to be attractive, yet accessible, be expressive and to transcend the television screen. Once they got the job, the unwritten rule behind keeping it was that they had to have an impeccable public image and maintain a respectable family life, as will be discussed later in this article.

\section{The Job Requirements for a New Medium}

The profession of announcer was transferred from radio to television, where it became known as 'in-vision announcer,' and the job requirements for television announcers articulate particular visions of early TV. Primarily, television was thought of as an audio-visual medium, which was distinctive from its predecessors: radio and cinema. The very first television announcers therefore, were selected to put a familiar face on the medium once known as 'radio with pictures,' and in these terms, to usher in and orchestrate the viewing experience associated with the new medium, into the domestic, private environment.

The identity of early television began under the shadow of radio as well as cinema. ${ }^{12}$ TV had been considered as 'radio with pictures' not only because of its combination of sound and image, but also for the centrality that sound had in television. ${ }^{13}$ On the other hand, television - just like cinema - was a moving image medium, and in its very early days when TV was screened in public theatres, the viewing experience of television coincided very much with the conventional experience of cinemagoers. As an important part of its institutionalization, efforts were made to distinguish television from its predecessors and to search for and establish its own identity.

Right from the beginning of television before World War II, the BBC introduced in-vision announcers to emphasize television as a visual medium in contrast to radio. "[N]obody will ever be able to deny that they [the first female

\footnotetext{
9 'Probe crainice', T 2133, 1970 and 'Probe concurs crainice', T3039, 1972, Romanian Television Archives.

10 Joanne Hollows, “Feeling like a Domestic Goddess: Postfeminism and Cooking', in: Charlotte Brunsdon and Lynn Spigel eds., Feminist

Television Criticism. A Reader, Open University Press, 1997, p. 167-169.

11 Elspeth Probyn, "New Traditionalism and Post Feminism: TV Does the Home" in Screen, Vol 31, 2, p. 152.

12 See further Michel Chion, Audio-Vision: Sound on Screen, eds. Claudia Gorbman, Columbia University Press, 1994; Siegfried Zielinski, Audiovisions: Cinema and Television as Entr'actes in History, Amsterdam University Press, 1999; Herbert Zettl, Sight Sound Motion: Applied Media Aesthetics, Thomson Wadsworth, 2005; Michele Hilmes, "Television Sound: Why the Silence?" in Music, Sound, and the Moving Image 2/2, 2008, p. 153-161; Michele Hilmes, Hollywood and Broadcasting: From Radio to Cable, University of Illinois Press, 1990.

13 See Rick Altman, "Television/Sound" in: Tania Modleski ed., Studies in Entertainment: Critical Approaches to Mass Culture, Indiana University Press, 1986, p. 39-54; John Ellis, Visible Fictions: Cinema, Television, Video, Routledge, 1982.
} 
announcers] gave television a distinctly visual flying start' claimed the television critic Kenneth Bailey in $1950 .{ }^{14}$ In this new televisual profession however, it was the voice combined with an attractive appearance that constituted the key to success:

It was the image that was important in this profession, but also the voice. Several people told me: "We grew up with your voice," remembered Delia Budeanu, former announcer on Romanian television. ${ }^{15}$

Video 2: Interview with Delia Budeanu, TVR, 18 August 2002

Similarly the very first in-vision announcer of Romanian television Mariana Zaharescu admitted:

I participated in the selection of two announcers for television and I won the job. I think I was chosen because of my youth and my voice. Don't take this as lack of modesty, but I was later on called the 'the golden voice... ${ }^{16}$

Vocal qualities were an important criterion in the selection of candidates for the job of in-vision announcers. Some of the Romanian announcers (e.g. Mariana Zaharescu, Delia Budeanu) first worked in radio before they were encouraged to apply for the position of television announcer. Just like their looks, their voices needed to transcend the television screen. Romanian continuity announcers spoke in soft, friendly, yet well-articulated voices and showed an impeccable mastery of Romanian language. Some of them had a background in philology and others in theatre, which testified to their mastery of language and performativity of voice. Dutch announcers, such as Tanja Koen, also admitted to have used their radio experience to perform on television. ${ }^{17}$ Apart from sounding 'professional,' voices needed to fit with a feminine, elegant appearance, which for Dutch presenters meant elegant voices, pleasant and well articulated at the same time, representing again a classic, stylish image to which no audience could take offence. No wonder most Dutch presenters also presented children's programmes. The vocal qualities of female announcers once again alluded to their envisioned bonding role between the sphere of the home and of the family and the sphere of the broadcast institution. They also indexed the ideology of middle-class femininity, which situated these women within the sphere of feminine domesticity despite their public image.

Continuity announcers performed a direct mode of address. This direct address was achieved not only by looking directly into the camera and adopting appropriate person-to-person forms of speech, but also through the use of words such as 'now,' 'today,' 'we,' which marked the announcer's talk on television and positioned them - and television by extension - in the 'here' and 'now.'18 The direct address instituted a sense of complicity and co-presence between the announcer and the viewer, and aligned the space of the viewer's home with the institutional space of the broadcast institution. ${ }^{19}$ In France, for instance, viewers were invited from the very beginning to participate in the selection process of female announcers, which instituted an interactive bond between this new television figure and the people, 'the viewers' at home.

\section{Video 3: The results of the French TV competition for in-vision announcers following the votes of the viewers, ORTF, 1964}

Continuity announcers across Europe addressed their viewers at regular times with phrases such as: 'good evening, ladies and gentlemen, 'we invite you to watch with us,' 'we bring to your home our selection of programmes.' These forms of speech enhanced the domestic environment of the viewers and positioned the continuity announcer and by extension, the broadcast institution, within the daily routines of the viewer. The direct address implied also a certain degree of 'performativity' and 'liveliness' on the part of continuity announcers. 'Performativity' related to a certain way

\footnotetext{
14 Bailey quoted in James Bennett, Television Personalities: Stardom and the Small Screen, p. 66

15 'Profesionistii. Delia Budeanu', interview by Eugenia Voda, Tape B 70732, Arhiva TVR, 18 August 2002.

16 Mariana Zaharscu quoted in 'Sticla. Mariana Zaharescu prima crainica din istoria TVR' in Jurnalul National, 20 December 2004

17 Interview with Tanja Koen, Sound and Vision, 18 May 2010.

18 John Ellis, Seeing Things. Television in the Age of Uncertainty, I.B. Tauris, 2000, p. 33

19 Paddy Scannell, Broadcast Talk, Sage, 1991, p. 32.
} 
of acting that was not 'actorly,' while 'livelines' meant 'looking lively' and 'talking as if spontaneously.'20 This explains why expressivity, naturalness, apparent ease in front of the camera and the ability to respond spontaneously were trademarks that broadcasters looked for in the selection process of continuity announcers.

Besides the voice and the performance of a direct form of address, the physical appearance of continuity announcers was equally important. Across Europe, female in-vision announcers were selected on the basis of their looks, and this criterion was listed in the job advertisements. '[A]ttractive announcers are obviously of first-class importance' read a BBC policy document that talked about the institution's first quest for in-vision television announcers. ${ }^{21}$ The first BBC female announcers Sylvia Peters, Mary Malcolm and Nöelle Middleton were selected following this approach, with the last one being recommended for the job due to her being 'attractive, charming, capable, ${ }^{22}$ while details that were forwarded to the Presentation Editor Clive Rawes concerning her suitability for the job included one line mentioning her experience as an announcer at Radio Eireann and full details of her bust, waist and hip measurements accompanied by pictures of her. ${ }^{23}$

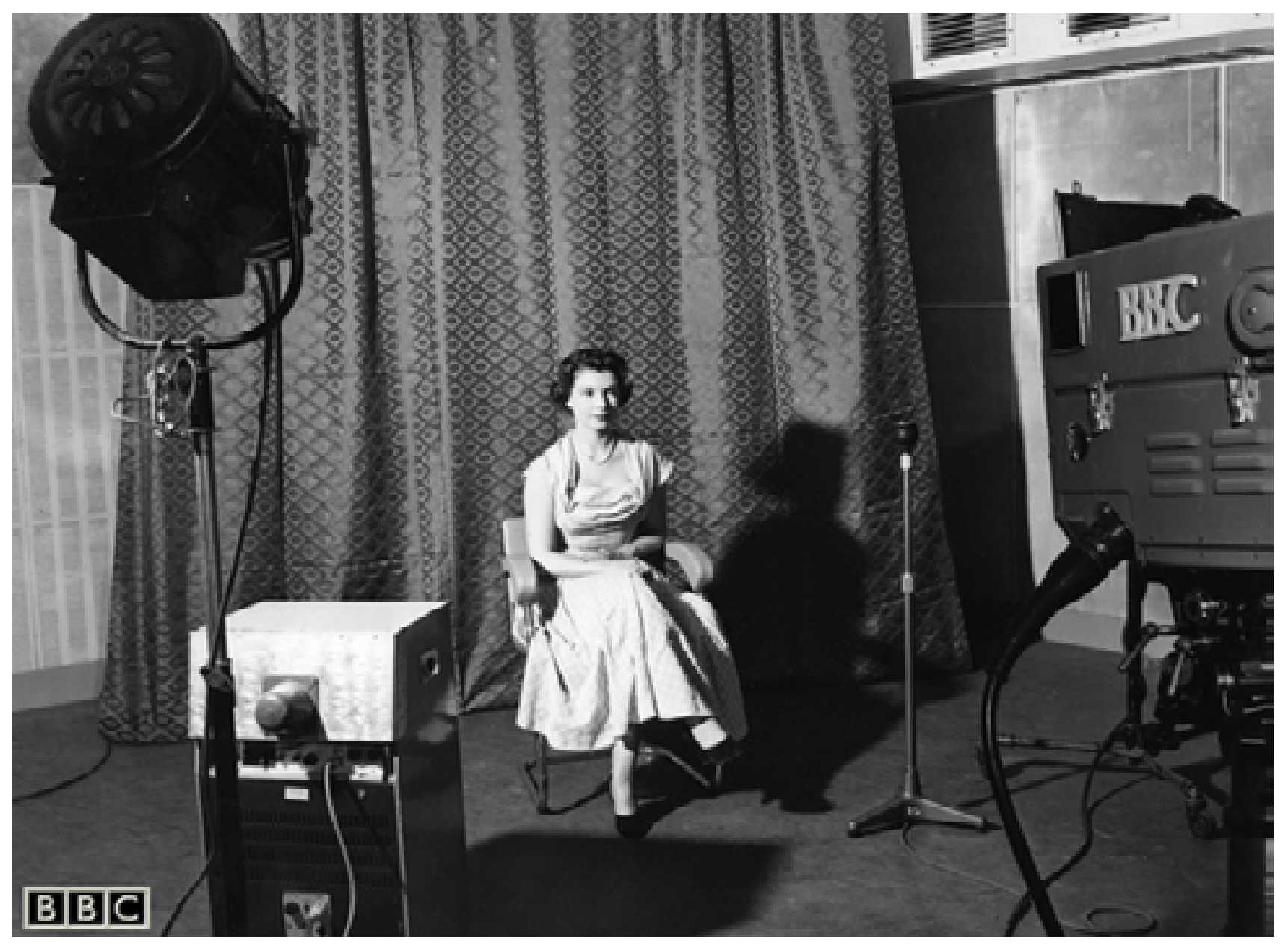

Photo 1: Sylvia Peters presenting at the BBC's Lime Grove Studios, BBC 1953

${ }^{20}$ Andrew Tolson, Media Talk. Spoken Discourse on TV and Radio, Edinburgh University Press, 2006, p. 10-11.

${ }^{21}$ BBC TV Policy General 1934-1939, 'Announcements', September 5 1935, T16/78 (BBC WAC), cited in Bennett, $2011: 70$.

22 'Cecil Madden to Clive Rawes, September 8 1952, NM File 1 (BBC WAC)', cited in Bennet, 2011, p. 70-71.

${ }^{23}$ Bennett, Television Personalities, 2011, p. 72. 
But it wasn't just any kind of looks that passed for the job requirements of the female in-vision announcer. Female announcers had to come across as ordinary, yet elevated and having an all important poise - in line with what a public service institution stood for. They had to have a warm personality that would transcend the screen into people's home, and had to inspire credibility and intimacy. The British television critic Kenneth Bailey related how the first director of television at the BBC, Gerald Cock 'knew that television comes intimately into the home, and that warmth of personality, without either affectation or artificiality, would be required of its announcers. ${ }^{24}$ Similarly, Langer ${ }^{25}$ and Marshall ${ }^{26}$ argued that in-vision announcers had to come across as the 'girl next door', as one able to present television as something homely that would be welcomed into the bosom of the family.

You had to transcend the screen, to imagine that behind the screen was a dear person you were talking to. I used to think of my grandmother when I was announcing, confessed Romanian announcer Delia Budeanu. ${ }^{27}$

Besides a resonant voice and attractive looks that would inspire warmth, credibility and intimacy, female television announcers also needed performance skills. While some of the hired in-vision announcers in early television had radio experience, others had theatre or artistic experience. Romanian announcer Silvia Ciurescu had been a ballerina, while Sanda Taranu had previously studied theatre before joining television.

\section{Video 4: Interview with Sanda Taranu about her 40-year long career in Romanian Television, Antena 3, 22 May} $\underline{2011}$

Television announcers combined the vocal qualities of radio presenters, the artistic talents of theatre performers with the eye-pleasing appearances required by a screen medium. However, the job requirements for television announcers indicate visions of television as a distinctive audiovisual (e.g. where both sound and image were important), domestic (e.g. announcers had to transcend the screen into the domestic home) and transnational (e.g. they had to speak different foreign languages) medium. Despite the profession bringing together skills from other media, in-vision announcers became essential mediators of early television's distinctive identity.

\section{In-vision Continuity Announcers as Mediators of Television's Domesticity}

In-vision announcers were selected from the very beginning with regard to their potential to enter the homes of the television viewers. As argued earlier, their physical and vocal qualities and their abilities to perform a direct mode of address played a key role in their selection process and these were utilized to create a bond between the viewer at home and the broadcaster. Despite this, the domesticity of television was not something that was inherent to television; it was rather primarily envisioned and was eventually the result of a process of 'domestication. ${ }^{28}$ As John Ellis has also argued: 'Nothing in television's technology determined that it should be a domestic medium.' ${ }^{29}$ In the 1950s after the institutionalization of television as a public service medium, the process of 'domesticating' television and incorporating it into the private space of the home began. This process conceived the home to be the 'ideal destination' for the television set, even though as Milly Buonanno has argued, television screenings kept appearing in public spaces. ${ }^{30}$ Domestication - alongside liveness and flow - was considered to be one of the dominant features that defined television's medial identity. ${ }^{31}$

24 Bailey, 1950: 6-7 cited in Bennett, 2011, p. 70.

25 John Langer, 'Television's “Personality” System' in Media, Culture \& Society, 3 (1), 351-365, 1981.

26 P. David Marshall, Celebrity and Power: Fame in Contemporary Society, University of Minnesota Press, 1997.

27 'Profesionistii. Delia Budeanu', interview by Eugenia Voda, Tape B 70732, Arhiva TVR, 18 August 2002.

28 Milly Buonanno, The Age of Television. Experiences and Theories, Intellect, 2008, p.14.

${ }^{29}$ Ellis, 2000: 31, cited in Milly Buonanno, The Age of Television. Experiences and Theories, Intellect, 2008, p.14.

30 Milly Buonanno, The Age of Television, 2008, p.14-17.

31 Jostein Gripsrud, 'Television, Broadcasting, Flow: Key Metaphors in TV Theory' in Christine Geraghty and David Lusted, eds., The Television

Studies Book, Arnold, 1998. Raymond Williams, Television: Technology and Cultural Form, Oxford University Press, 1992 (1974). 
In this process of domestication, audiences had to be made sensitive to appropriating television and accommodating the new medium into their homes. To that purpose popular discourses of television had to be constructed, which both implied and mobilized an 'imaginary' consumer. With the help of advertisements in newspapers, lifestyle or family magazines, not to mention the television guides, TV was promoted - primarily in the West - to confirm the ideal of the middle class (bourgeois) family with its existing gender roles. ${ }^{32}$ Television announcers thus, played a central role in mediating early television as a domestic medium, 'invisibly' representing the middle class notion of consumerism in postwar Western Europe. In 1960s Romania, consumer home technologies such as the television set fitted into the image of a modern, urban life that the Ceausescu ? regime was promoting. Continuity announcers became thus representatives of a modern lifestyle, balancing between the exceptional and the ordinary, they were able to mobilize their audiences into a cultural community of viewers, offering them a space for the consumption of modern life, as articulated through their modern, yet decent clothing, their voices, and most of all their embodiment of the new medium, a luxury electronic good that stood as symbol for modern consumerism. In this vein John Hartley discusses broadcast television in the context of the suburban experience in terms of a 'representational regime,' pointing to its domestic setting, its live immediacy, its leisure-time availability, 'casual continuity, operational simplicity and the human scale of its screen. ${ }^{33}$ As we will argue, in-vision announcers were placed at the centre of this process of domestication; they spoke precisely for continuity and simplicity and put a human face to the new technology, thus giving the home consumer access to the modern experience.

My profession required a very special connection to the viewers. [...] Many times I would read the letters from viewers the moment I would arrive at the television center, just before I would go on air. That is what gave me the spirit I had when I was talking to the viewers at home, confessed Romanian announcer Sanda Taranu. ${ }^{34}$

Besides their on-screen appearances that would fit this desired ideology of middle-class femininity, the television announcer also performed, publicised off-screen roles that were associated with family and home, such as: the role of mother or wife or simply the role of the woman in her own domestic space. Italian in-vision announcers Alessandra Pacini, Nicoletta Orsomando, Gabriella Farinon or Emma Danieli provide examples here:

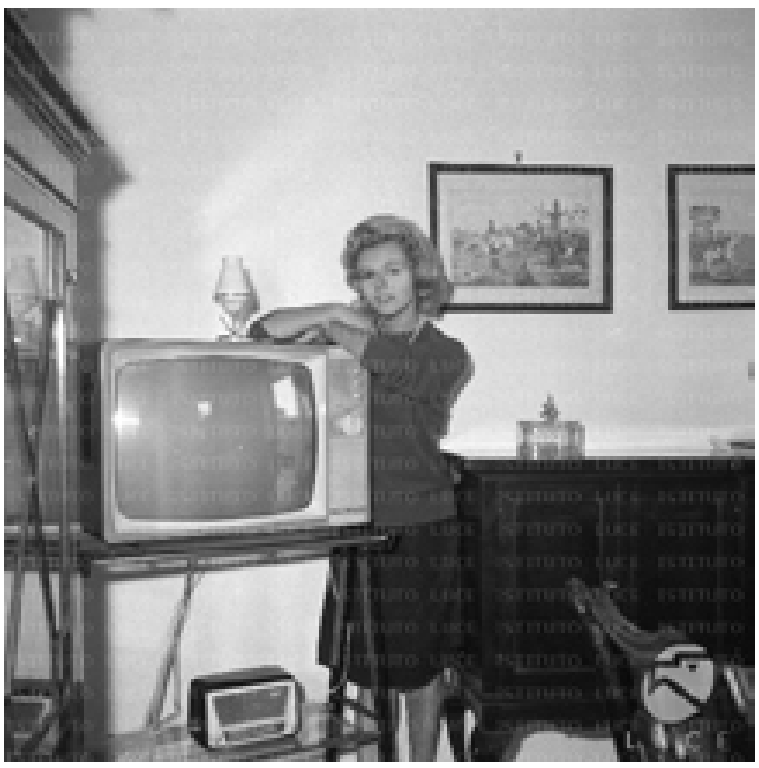

Photo 2: Alessandra Pacini posing next to a domestic television set, Cinecittà Luce, 1962

\footnotetext{
32 See among others Lynn Spigel, Make Room for TV. Television and the Family Ideal in Postwar America, University of Chicago Press, 1992. 33 John Hartley, 'Less popular but more democratic? Corrie, Clarkson and the dancing Cru', in Graeme Turner and Jinna Tay, eds, Television Studies After TV. Understanding Television in the Post-Broadcast Era, Routledge, 2009, p. 20-30, p. 21.

34 Interview Sanda Taranu, In Premiera cu Carmen Avram, Antena 3, 22 May 2011.
} 


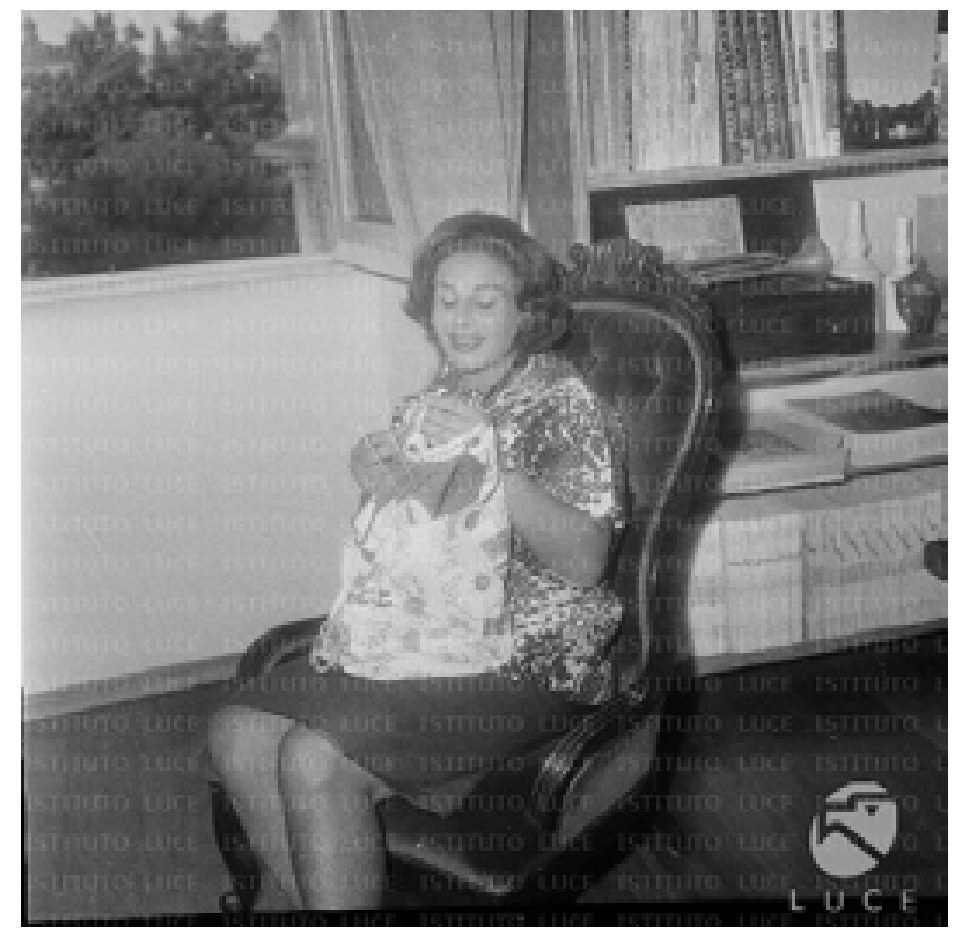

Photo 3: Nicoletta Orsomando posing knitting at home during her pregnancy, Cinecittà Luce, 1960

Video 5: Interview with announcer Gabriella Farinon in her home as the mother of 2-year old Barbara, Cinecittà Luce, 1965

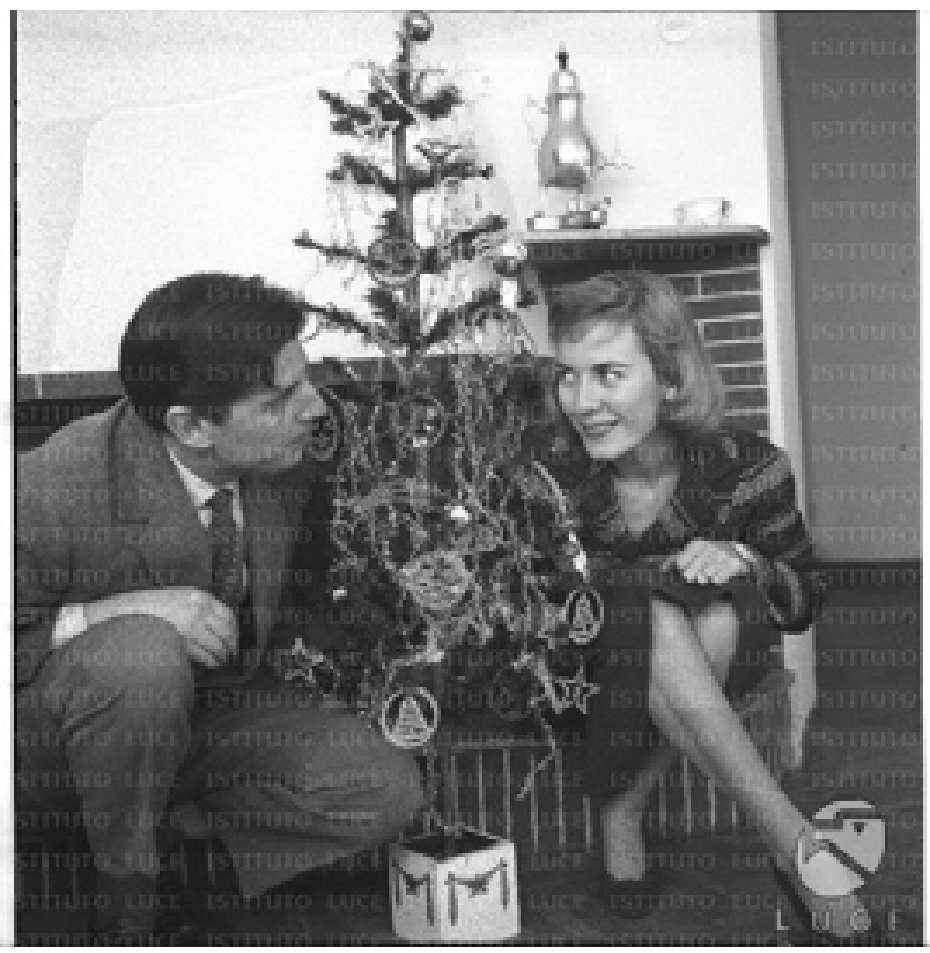


In this context it is also telling that Dutch announcers were featured on television programmes that celebrated a certain number of viewers. Their appearance on these programmes performed a linkage between the Dutch viewer and the new televisual medium. When Dutch television celebrated the $250.000^{\text {th }}$ viewer in 1958 and the $500.000^{\text {th }}$ in 1959 or the one million viewer in 1961, the announcers featured prominently in programmes such as Welcome 500.000 television viewer, NTS, 24 July 1959 or The 250.000 television viewer, NTS, 21 January 1958. They were part of the 'caravan' that visited the particular viewer at his or her home. The announcers appeared in the show in a special horse carriage, surprising the viewer at home with their presence and brought consumables for each family member such as: slippers, cigars or a mobile television table, which helped further accommodate the new medium into the home.

Video 6: In-vision announcers handing out presents in the home of the 500.000 television viewer in Welcome $\underline{500.000 \text { television viewer, NTS, } 1959 .}$

In other programmes, Dutch announcers evoked the ideal of marriage and family. When the Dutch announcer Hannie Lips got married on June $3^{\text {rd }}$, 1960, her colleagues Ageeth Scherphuis and Karin Kraaykamp congratulated her on the national news bulletin, which also featured a short reportage on Lips' marriage. On July $20^{\text {th }}, 1960$ the national television news reported on the marriage of Ageeth Scherphuis herself. ${ }^{35}$ Off-screen appearances like these reconfirmed the ideology of middle-class femininity that these women were supposed to fulfil.

Female television announcers, through their warm appearances on the screen and in their direct contact with the viewers, did not only facilitate the integration of the new televisual technology into the home, they also facilitated television becoming part of the daily rhythm of life. With their direct and routine address: 'good evening, ladies and gentlemen' or 'good night, everyone', the in-vision ladies helped the structuring of the rhythm of everyday life.

One time when I was in hospital, few women came to me and told me they were in hospital because they could not get any sleep. They approached me and asked me to wish them 'good night' just like I would do it on television, hoping that they could fall asleep that way, remembered Sanda Taranu. ${ }^{36}$

Similarly, female announcers in different countries also marked the changing of years as for instance, they presented the New Year's festivities on television.

Video 7: Romanian announcer Cleo Stieber saluting the viewers on New Year's Eve 1957, TVR

Video 8: Belgian announcer Paula Semer making the New Year wishes on 31st December 1953

\section{Popularizing the New Medium}

While on the screen in-vision announcers evoked the warmth of the home and family life and won the admiration and trust of viewers at home, in public they became key players in popularizing the new televisual medium. In Ireland, for example, female announcers walked into the streets to meet viewers as part of organized meetings, successfully performing their role as 'the girls next door'. The example of Irish television announcers who toured Ireland to meet and introduce themselves to people, took place prior to the opening night of Irish television in 1961. In the Netherlands, television announcers also performed as 'lady speakers' at fashion and flower shows, at fairs and store openings, combining their role of popularizing the new medium, with mediating modern consumerism. These 'reallife' appearances of continuity announcers were a public extension of their on-screen direct mode of address and the

35 Interview with Ageeth Scherphuis, Sound and Vision, 6 January 2011.

36 Interview Sanda Taranu, In Premiera cu Carmen Avram, Antena 3, 22 May 2011. 
'quasi-interactive' involvement with the viewers that they sought to promote. ${ }^{37}$

It is worth noting that the job of the early in-vision announcer did not only presuppose the announcing of programmes, but also the introduction of the new televisual technology to viewers as well as educating them in relation to the new medium: 'We were explaining about the content of the programmes we announced' confessed Dutch announcer Ageeth Scherphuis. ${ }^{38}$ Besides announcing programmes, the Dutch announcers also explained and introduced the medium as a novelty in other programmes, mainly children's programmes, which most of them presented and also hosted ${ }^{39}$

Video 9: French announcer Jacqueline Joubert introducing the new technology of television to viewers, INA, 1951.

While popularizing the new medium, in-vision announcers had become popular television figures and celebrities themselves, emphasizing warmth, credibility and their 'girl next door' appeal. This was unlike the status of cinema stars that were more often constructed as glamorous and unattainable. Yet, in their acts of self-representation female announcers provoked admiration, supported by their pictures published on the covers of the television guides, in lifestyle magazines and by publicizing clips of their private lives in the public sphere. In the context of modern life however, television announcers performed one particular function that Richard Dyer ${ }^{40}$ has attributed to 'stars', namely the holding together of contradictory social ideals. This is to say they represented the middle class ideal of modern life, among other things in speaking the language of the middle class, without any dialect or accent, while at the same time purporting to appeal to all social classes and binding them together. As in the Netherlands each announcer represented one of the existing broadcasting companies, one could argue they also represented the cultural values of the broadcaster they were working for, thus offering a space for the consumption of apparently 'plural' notions of cultural identity.

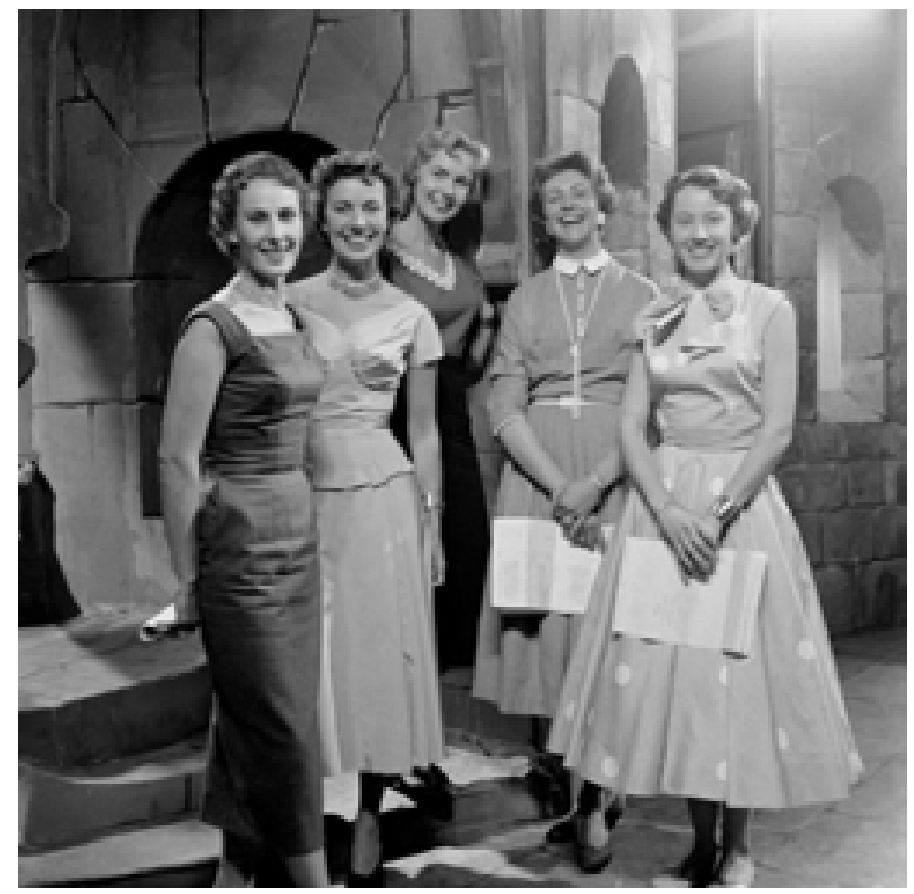

Photo 5: Group photo announcers of Dutch public broadcasters, NTS, 1956

\footnotetext{
${ }^{37}$ Andrew Tolson, Media Talk. Spoken Discourse on TV and Radio, Edinburgh University Press, 2006.

38 Interview with Ageeth Scherphuis, Sound and Vision, 6 January 2011

39 Mies Bouwman, Goedenavond dames en heren! Close-ups en long shots uit de televisiewereld, De Boer jr., 1956, p. 65-66.

40 Richard Dyer, Stars, British Film Institute, 1979, p. 49.
} 
In Romania, while the regime politics required that celebrity status be kept firmly under control, the announcers remember being popular and approached by people in the streets.

People would stop me in the street to touch my hair and reassure themselves that it was all natural. It was very curly and they thought it might be a wig. Then they were very curious to see my legs. On TV, I would only appear in medium close-up, so in person they wanted to check me out in detail, remembered the Romanian announcer Mariana Zaharescu. ${ }^{41}$

Testimony to the widespread popularity of female in-vision announcers was also provided in the great number of letters they received from viewers. 'I think I was receiving more letters than the entire institution,' remembered Romanian Sanda Taranu. ${ }^{42}$

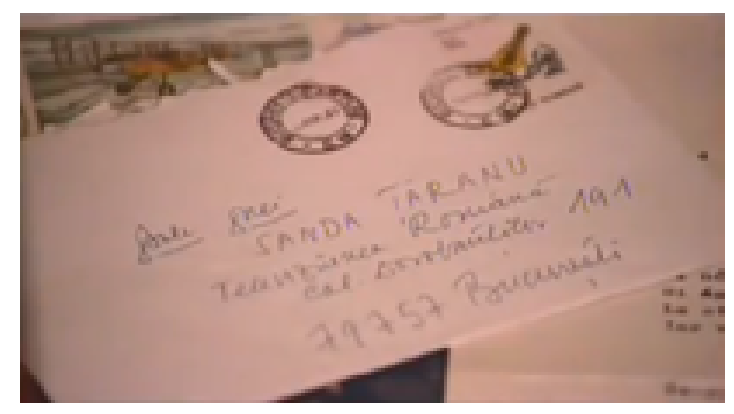

Photo 6: A letter from a viewer addressed to Sanda Taranu, In Premiera cu Carmen Avram, Antena 3, 22 May 2011.

\section{In-vision Continuity Announcers: The Image of Public Broadcasters}

The job specification of the in-vision announcers also required that they would abide by, represent and uphold the values of the respective public broadcaster.

On the screen, female announcers represented discourses of 'respectable glamour'43 that stood for ordinariness, intimacy and authenticity. To support that discourse, in the Netherlands, female announcers appeared on the screen dressed in fashionable, yet not revealing dresses or wearing a striped blouse that served as fashion model for the modern woman. In Romania, in-vision announcers also had to wear clothes that were approved by the public broadcaster and suitable for the time of day and the programmes they were presenting. 'When the institution had money, they would make two dresses for us, six blouses and a skirt per year. We had to give them back, they were not ours, they belonged to the institution. And they would re-use them afterwards in theatre plays,' said Sanda Taranu. ${ }^{44}$

\footnotetext{
41 'Sticla. Mariana Zaharescu prima crainica din istoria TVR' in Jurnalul National, 20 December 2004.

42 Interview Sanda Taranu, In Premiera cu Carmen Avram, Antena 3, 22 May 2011.

43 Beverley Skeggs, Formations of Class and Gender, Sage Publications, 1997, p. 110.

44 Interview Sanda Taranu, In Premiera cu Carmen Avram, Antena 3, 22 May 2011.
} 


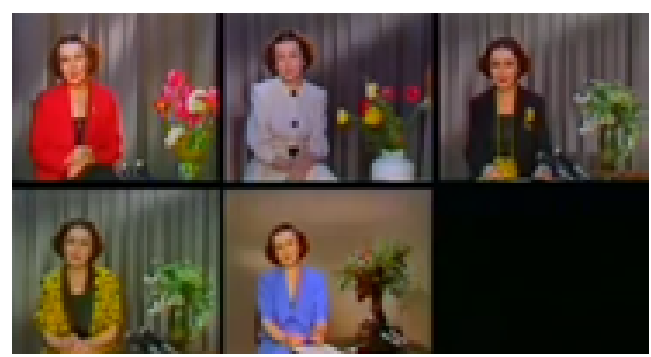

Photo 7: Sanda Taranu in various outfits while presenting, In Premiera cu Carmen Avram, Antena 3, 22 May 2011.

Off the screen, female announcers had to act as public persona that represented the ideal of the middle class nuclear family with the existing gender roles. Any deviance from these ideal roles could be penalized with the termination of contract. This was the case of the Dutch announcer Mies Bouwman who started dating a divorced cameraman and in 1953 was asked to leave the Catholic broadcaster she had been working for since $1951 .{ }^{45}$ In Romania, the contract of Mariana Zaharescu was terminated when her sister married an Italian citizen, which contravened the family ideals envisioned by the Communist Party. ${ }^{46}$ The family background of the female announcers had to match the identity and the ideals of the broadcaster they were working for. In the Netherlands, some announcers identified themselves with the different social and religious pillars represented by each broadcaster. Tanja Koen felt she really represented the Christian Protestant broadcaster, ${ }^{47}$ while Elizabeth Mooij considered herself 'a true AVRO (referring to the general, least conservative Dutch broadcaster) person. ${ }^{48}$

I was an image. [...] You had to be all the time the character you were on the screen. I've lived all my life with a strict supervision over myself. [...] The profession of in-vision announcer was an institution, the emblem of a broadcast institution,' concluded Romanian announcer Delia Budeanu while talking about her profession. ${ }^{49}$

\section{In-Vision Continuity Announcers as Mediators of Television's Transnationality}

Being the image of a specific broadcaster was not only a local or national duty, it also extended across national borders as in-vision announcers had to perform at international events and protocol visits and present exchange programmes. While in their own countries continuity announcers were linked to the ideal image of home and family life as well as the values of public broadcasting (e.g. ordinariness, authenticity, credibility, 'respectable glamour'), across the borders they performed as 'television ambassadors' of national broadcasters.

In various countries, in-vision announcers presented international television events such as the Eurovision Song Contest. Belgian announcer Paula Semer was sent to London in 1954 to represent Belgium at the first Eurovision broadcast. She had to perform at the Eurovision show at the BBC and announce in Dutch. ${ }^{50}$ Karin Kraaykamp also represented the Netherlands at the same event. All countries present articulated a particular message. Kraaykamp said she hoped that Eurovision would enhance and positively impact on mutual understanding among European nations. Thinking back on this moment in 2010, Kraaykamp recalls that this message was naïve and very much bound

\footnotetext{
45 Mies Bouwman and Jeroen Van den Berg, Mies. 25 1/2 jaar TV. Omzien in verbazing, Veen, 1977, p. 48-51.

46 'Sticla. Mariana Zaharescu prima crainica din istoria TVR' in Jurnalul National, 20 December 2004.

47 Interview with Tanja Koen, Sound and Vision, 18 May 2010.

48 Interview with Elizabeth Mooij, Sound and Vision, 29 September 2010.

49 'Profesionistii. Delia Budeanu', interview by Eugenia Voda, Tape B 70732, Arhiva TVR, 18 August 2002.

50 Ronald Grossey, Goedenavond, beste kijkers. De televisie in zwart-wit, van 31 oktober 1953 tot 31 december 1970, Standaard, 1993, p. 157.
} 
up with early visions of the potential role of television that made one feel 'we belonged to Europe.'51 In Romania, female in-vision announcers presented the annual International Music Festival 'The Golden Stag,' an event that brought together renowned musicians from around the world.

\section{Video 10: Romanian in-vision announcers performing on the stage of the International Music Festival 'The Golden Staq' TVR, 1970.}

Right after the coronation of Queen Elizabeth II in 1953, with the Eurovision connection between France, Belgium and the Netherlands still in the air, Mies Bouwman traveled to Paris, as the Dutch broadcaster considered it appropriate to accompany programmes on Dutch television coming from France with a Dutch in-vision announcer. She recalls how she also had to replace a French colleague who fell ill and how much Eurovision at the time had to deal with constant technical disturbances..$^{52}$

Apart from presenting at international televised events, in-vision announcers also participated in protocol visits and took part in international meetings. Tanja Koen represented all Dutch announcers at the BBC's 20-year celebration in 1956, where she met announcers from across Europe. The Belgian announcer Paula Semer, for instance, visited the Dutch region Limburg together with other television officials of Flemish television. On a courtesy visit paid by Czechoslovak television to Zagreb, the Czechoslovak team met up with the popular Croatian announcer Gordana Boneti.

Video 11: Footage from the visit of Czechoslovak television to Zagreb, including also an interview with the Croatian announcer Gordana Boneti, Československá televise, 1968.

In Romania, female announcers joined forces with announcers from foreign broadcasters to present duplex programmes that were being broadcast simultaneously in the two different countries. Such were the Seara televiziunii cubaneze ('The Evening of Cuban Television'), a full-evening programme presented by Silvia Ciurescu together with a colleague from Cuban Television. ${ }^{53}$ The two announcers would present the programmes alternatively, with Silvia Ciurescu translating the Spanish parts of her colleague in Romanian for the Romanian viewers. Similarly, Sanda Taranu presented the duplex programme Alo Bucuresti, aici Sofia ('Hello Bucharest, this is Sofia calling') together with a Bulgarian colleague. The programme was filmed both in Sofia and Bucharest and was bilingual RomanianBulgarian and was broadcast to audiences in the two countries. The two announcers walked together on the streets of Bucharest and Sofia and introduced their main attractions to viewers. 'It's easy to travel from Sofia to Bucharest by means of television,' commented Sanda Taranu. The two announcers would eventually arrive at the Romanian Television Centre where Sanda Taranu introduced her workplace to her Bulgarian colleagues and to the viewers at home.

Video 12: Alo Bucuresti, aici Sofia ('Hello Bucharest, this is Sofia calling'), TVR, 1978

Video 13: Romanian announcer Sanda Taranu presenting an artistic moment from Bucharest and Belgrade to both Romanian and Yugoslavian audiences, In Premiera cu Carmen Avram, Antena 3, 22 May 2011.

Female in-vision announcers across Europe performed as the image of public broadcasters both within and across the country's borders. They became transnational ambassadors of national institutions and more than that; they performed an envisioned role of television as able to consolidate relations between different countries (as was the case with the Romanian duplex programmes) or mutual agreement among European countries (as the Dutch announcer Karin Kraaykamp remembered regarding her presenting at Eurovision).

\footnotetext{
51 Interview with Karin Kraaykamp, Sound and Vision, 11 October 2010.

52 Mies Bouwman, Goedenavond dames en heren! Close-ups en long shots uit de televisiewereld, De Boer jr., 1956, p. $130-131$.

53 'Seara Televiziunii Cubaneze', Tape F1615014/2, Romanian Television Archives, 1979.
} 


\section{The Mediation of Television as a Gendered Medium}

We have suggested that the characters that female television announcers across Europe performed on and off the screen mediated a gendered conceptualisation of the medium that promoted an ideology of middle-class femininity. Not only did they perform a refined version of the modern woman, they were also able to personalize the medium in a soft (feminine) way as a domestic pastime. The announcers acted as friendly, presentable mediators, rather than initiators of television programmes. They had to read most often a pre-written text, which they had to learn by heart as there was no auto-cue and no scripts were allowed on the desk. Off the screen they represented discourses of femininity and evoked traditional images of the home and of the family. Memorable in this sense were the televised celebrations of the $250.000^{\text {th }}$ or $500.000^{\text {th }}$ television viewer in the Netherlands, where the Dutch in-vision announcers who visited the viewers at home were not allowed to step out of their roles as charming hosts. They did not do any of the interviews with the viewers about their television experiences (those were performed by the male hosts) and instead they disappeared into the background making coffee and serving tea. ${ }^{54} \mathrm{All}$ this reinforced the ideal of domestic, middle-class femininity that they were expected to embody: the ideal of women choosing for family and domestic values at the expense of a career.

Women entered the television industry first and foremost as in-vision announcers. Besides their announcing jobs, some of them also presented other 'soft' programmes, such as children's programmes. However, most of the invision announcers broke out of their gendered position inside the broadcast institutions. In the Netherlands, this only happened after several years and the opportunity to do so depended on the broadcaster they represented. Announcers working for the Social Democratic and Liberal Protestant broadcasters were not allowed to do anything more than just announcing. That is why after about ten years of working as an announcer, they often left the job to pursue a career outside television. This is what happened with Karin Kraaykamp who was working for VARA (the Social Democratic broadcaster) and went on to work in business. Another Dutch announcer Tanja Koen, who was married to a television director, started after ten years of announcing, to present (animal) programmes for children at the Christian Protestant broadcaster. The same happened with Hannie Lips - also known as 'Auntie Hannie - who was working for the Catholic broadcaster. Only Ageeth Scherphuis working for the Liberal broadcaster and Mies Bouwman working for the Catholic broadcaster were able to pursue television careers. Ageeth Scherphuis had worked as a journalist for the national newspaper before she came to work in television. From the start she had the ambition to continue her journalistic work next to announcing programmes. This wasn't easy for women as she recalls, yet she was initially allowed to contribute to children's programmes. Only from 1964 onwards did she manage to start presenting and switched to other broadcasters. In her own words, she became a 'pleasant' feminist and advocated the rights of women to do more then only announcing..$^{55}$ The most famous Dutch announcer Mies Bouwman started working for the Liberal broadcaster in 1955, after having been laid off in 1953 by the Catholic broadcaster due to what was regarded as inappropriate dating behaviour. Soon after she started with the new broadcaster, she began making television interviews and hosting talk shows and continued doing so until the early 1990s (with the exception of a short employment period with the Social Democratic broadcaster in the 1960s).

The case of in-vision announcers who succeeded in carving out a remarkable career in television also occurred in other countries. In Belgium for instance, announcer Terry van Ginderen, originally a singer, started presenting children's programmes in 1962. ${ }^{56}$ Paula Semer - also known as 'Auntie' Paula Semer - started presenting and producing other television programmes in 1960, especially cultural and education programmes. One of the key programmes she became responsible for was Penelope, which Semer started presenting in 1955 and also produced in 1958. Initially, the programme reflected a consumer-based society that covered topics such as: cooking, life style and other household activities. Paula Semer soon changed the identity of the programme and chose a more critical tone for it, advocating the emancipation of women. She undertook a new activist role in this programme, which was heavily criticized by viewers who knew her as a friendly and engaging person and couldn't match the new Paula

\footnotetext{
54 Programmes The 250.000 television viewer, NTS, 21 January 1958 or Welcome 500.000 television viewer, NTS, 24 July 1959.

55 Interview with Ageeth Scherphuis, Sound and Vision, 6 January 2011.

56 Ronald Grossey, Goedenavond, beste kijkers. De televisie in zwart-wit, van 31 oktober 1953 tot 31 december 1970, Standaard, 1993, p. 55-56.
} 
Semer with the 'old' one ${ }^{57}$ In the programme Semer debated feminist issues, such as: equal pay for men and women or coping with single motherhood, and she became an active feminist in her later career.

A similar change in the viewers' attitude happened in the Netherlands when Mies Bouwman became heavily criticized in the 1960s when working for the Social Democratic broadcaster, for her role as presenter of a controversial satirical programme that mocked religion, politics and monarchy. The Dutch announcer Ageeth Scherphuis also started making more overtly feminist programmes, drawing on her former work as a journalist.

In communist Romania that advocated equal rights for men and women and where women were envisioned to have both a family and a work life, in-vision announcers were given more freedom to prove themselves in their workplace. At times they were allowed to write their own scripts; they also presented news, made interviews and were involved in the making of different social and women's programmes. Throughout their performances on the screen, they embodied the model of the socialist working-woman that projected a balance between family and the workplace, a life where family values as well as work ethics were deemed important. In the 1967 programme Emisiune pentru femei ('Programme for women'), Sanda Taranu interviewed an architect about his profession and asked him about his views on the role of the father within the household and in raising the children. In the same programme, she interviewed his wife about the equal distribution of tasks in their household. At the end, Sanda Taranu didn't shy away from confessing: 'My husband helps me very much with the household chores and he has no prejudices about this. ${ }^{.58}$

Later on in her career, Sanda Taranu continued to present and make her own programmes such as Un zambet pentru varsta a treia ('A smile for the elderly'), translated news items that were coming in from the BBC or drafted commentaries for the documentary programme Teleenciclopedia. Another early in-vision announcer loana Magura, for example, fled the country in the mid 60s and became an anti-communist activist working for the Romanian office of Radio Free Europe based in Munich. Another early Romanian announcer, Mariana Zaharescu also went on to secure the voice-over commentary for Teleenciclopedia.

These later careers of continuity announcer's bear testimony to how these extraordinary women attempted - by means of television - to negotiate and to challenge the ideological mould of domestic femininity that they had initially been selected to embody.

\section{Conclusions}

With their faces, voices and personalities performing a particular ideology of middle-class femininity, female in-vision announcers fulfilled a key role in the development of television history across Europe. They mediated the identity of television as an audio-visual and domestic medium, popularized and domesticated its consumption and promoted their broadcast institutions abroad. In doing this, they mediated and articulated important processes in the development of television and they did so in remarkably similar ways across countries, regardless of the East/West European divide. The professional in-vision announcer was the bearer of the same codes of etiquette across Europe and they were cast into very similar roles on and off the screen.

By mediating the identity, domestication and popularization of television institutions in similar ways locally and across Europe, in-vision announcers shaped a trans-national phenomenon of televisual development that assumed the same form, albeit with different faces in different national settings. Collectively however, they shaped a shared culture of early television in Europe. The contributions of female in-vision announcers to early television remain currently understated in television scholarship. Their value and significance however, as more than just 'respectably glamorous' presences on the screen, is in many cases, evidenced by the ways in which they forged later careers, turning them

57 Ronald Grossey, 1993, p. 184-188.

58 'Emisiune pentru femei', film roll T55220, Romanian Television Archives, 1967. 
from attractive women into active feminists and talented television professionals. It might be argued that their later careers and the feminist positions that some of them adopted contradicted and challenged the very ideology of femininity that was responsible for their recruitment and training in the first place. Beyond and behind the female invision announcer as a mere image and object of admiration on the screen only begins to reveal the actual historical complexities of their profession at that time.

Van den Bulck and Enli59 have already argued that female continuity announcers in Flanders and Norway performed particular roles in early television that were fully consonant with the articulation of the defining characteristics for the new medium of television (e.g.: liveness, flow, direct address and national, institutional emblem). We hope to have demonstrated in this article that the commonalities behind this role across Europe provide evidence for women continuity announcers being a key element in a shared European television history. Their place in European television history attests not only to their influential mediation and embodiment of a particular kind of televisual identity, but also to shared processes of televisual identification, popularization and transnationalization that took place across Europe in the 1950 s and 60s.

\section{Bi ography}

Sonja de Leeuw is Professor at the Department of Media and Culture Studies at the Utrecht University. Her research and teaching interests are Dutch television culture in an international context (history and theory genres and productions practices) and Media and cultural diversity (diasporic media, representation of ethnicity). She published on television culture in the broadest sense, on diasporic media and on children's media. Sonja de Leeuw participated in the EU funded research project CHICAM, Children in Communication about Migration (2001-2004) and coordinated the EU funded projects Video Active, Creating Access to Europe's Television Heritage (2006-2009) and EUscreen, Exploring Europe's Television Heritage in Changing Contexts (October 2009-2012). She is also co-leader of a research project The Power of Satire: Cultural Boundaries Contested. She co-founded and coordinates the European Television History Network (with dr. A. Fickers, University of Luxembourg).

Dana Mustata is Assistant Professor in Television Studies at the Department of Media and Journalism Studies at the University of Groningen. She is specialized in Romanian television history. She completed her PhD in 2011 with a dissertation on a first history of Romanian television entitled: 'The Power of Television: Including the Historicizing of the Live Romanian Revolution.' She is currently working on the project 'Everyday Matters. Material Historiographies of Television in Cold War Contexts' and leading the collaborative project 'Television Histories in (Post)Socialist Europe.' From 2006 until 2012 she has worked on the EU funded projects Video Active and EUscreen. She is co-founder and coordinator of the European (Post)Socialist Television History Network, member of the Television Studies Commission of the International Federation of Television Archives and a member of the European Television History Network.

${ }^{59}$ Hilde Van Den Bulck and Gunn Sara Enli, 2012. 